\title{
Woman's Resistance as Seen in Jane Eyre and Wide Sargasso Sea
}

\author{
Anna Anganita Theresia Latumeten \\ Balikpapan University \\ anna@uniba-bpn.ac.id
}

\begin{abstract}
:
This paper focuses on the depictions of the mad woman figure in two novels, Jane Eyre by Charlotte Brontë and Wide Sargasso Sea by Jean Rhys. Using comparative literature, both texts are seen in the light of woman's resistance as depicted by the characters "Bertha Mason" and "Antoinette Cosway" from Jane Eyre and Wide Sargasso Sea, respectively. The novels used in this descriptive study are the primary texts. The findings show how Wide Sargasso Sea shows women's resistance when being compared to Jane Eyre, giving the mad woman character a voice on her own and showing an attempt to free herself from the forms of domination she experiences.
\end{abstract}

Keywords: woman's resistance, Jane Eyre, Wide Sargasso Sea

\section{INTRODUCTION}

Jane Eyre is a novel written by English writer Charlotte Brontë, and was published in October 1847. Jane Eyre could be summarized as the story of Jane's trials and tribulations on becoming Mrs. Rochester. It is structures as a reflection of her journey as she progresses from her childhood and moves from place to place: from Gateshead to Lowood, Thornfield, Moor-House, and finally settles in Ferndean. Each place offers different experiences to Jane, both positive and negative experiences, and those places teach her something new about society or herself as she encounters different and variety of people, and they play an important part in Jane Eyre's discovery of self (Brennan, 2010, p.15).

The most important turning point in Jane Eyre's life is when she becomes a governess in Thornfield for a young French girl named Adéle Varens. She soon meets her employer Edward Rochester and falls in love with the man as the two come to enjoy each other's company and spend a lot of time talking to each other. However, Jane Eyre starts to take notice of numerous strange things that happen during her stay in the Thornfield. These 
strange things include her hearing strange laugh, a mysterious fire in Mr. Rochester's room, or Mr. Rochester guest-Mr. Richard Mason-being attacked. Jane, however, is forced to remain silence about the whole situation and pretend as if nothing has happened and continue to live normally. Even during her wedding preparation, a strange looking woman comes to her in her sleep and rips her wedding veil into two. She describes this strange looking woman as follows:

"It seemed, sir, a woman, tall and large, with thick and dark hair hanging long down her back. I know not what dress she had on: it was white and straight; but whether gown, sheet, or shroud, I cannot tell... I never saw a face like it! It was a discoloured face-it was a savage face. I wish I could forget the roll of the red eyes and the fearful blackened inflation of the lineaments! ... the lips were swelled and dark; the brow furrowed: the black eyebrows widely raised over the bloodshot eyes. Shall I tell you of what it reminded me?” (Brontë, 2014, p. 280)

Mr. Rochester soon comes to admit that this woman is his wife, named Bertha Mason. He admitted that his father and his brother tricked him into marrying this woman for the money, and he then discovered that Bertha was soon descending into madness and so he locked her away in Thornfield's attic, with a nurse named Grace Poole to take care of her. At times, when Grace gets drunk, his wife escapes and causes the strange happenings at Thornfield.

This figure, Bertha Mason, seems to interest Jean Rhys, a Dominica-born British author who then wrote Wide Sargasso Sea and published it in 1939. Wide Sargasso Sea gained a widespread interest for the novel is claimed to be a post-colonial reaction to Brontë's Jane Eyre.

Wide Sargasso Sea is written as the prequel and response to Brontë's Jane Eyre, Rhys uses the novel to describe the background of Mr. Rochester's marriage to Bertha Mason. By Rhys, Bertha Mason is not only given a voice, but also a background of the life she lived before she is brought to England by Edward Rochester. Bertha Mason, as known in Jane Eyre is a daughter of Jonas Mason, merchant, and of Antoinette, his wife, a Creole. Edward Rochester and Bertha Mason were married at a church in Spanish Town, Jamaica (Brontë, 2014, p.287). In Wide Sargasso Sea, we learn that Bertha Mason's name was originally Antoinette Cosway, and she is married to a certain English gentleman whose name never mentioned by the author. Antoinette Cosway, being a Creole, is caught in an oppressive patriarchal society, in which she does not belong to either White Europeans or the Black Jamaicans. Antoinette Cosway, just like Jane Eyre, experiences a rather difficult childhood as well. As we come to the end of Wide Sargasso Sea, in fact, we also learn how is this figure being oppressed and gradually becomes mad, just like the madwoman in the attic we know in Jane Eyre.

Since the publication, there has been various critics on how Wide Sargasso Sea is perceived, especially considering that this novel is a postcolonial response to Jane Eyre. The postcolonial argument in Rhys writing particularly concerns on how Bertha Mason's 
madness is tied to her Creole heritage. Just like how Charlotte Brontë's Jane Eyre has been suggested to have a proto-feminist ideal, so has Jean Rhys's Wide Sargasso Sea. There are numerous evidence on how the female figure - particularly Antoinette Cosway, has gone through serious oppression, especially considering of her race and gender. The novel shows how this minor character in Jane Eyre deals with the unequal power between men and women, especially in marriage. In regard to the different backgrounds of both authors, there must be different views on how both of them situating the character Bertha Mason, especially considering that Bertha Mason is just another minor character in Jane Eyre which barely has a 'voice'. Therefore, this paper focuses on seeing the character Bertha Mason, written by both Charlotte Brontë and Jean Rhys, and how both versions of 'Bertha Mason' react to the male domination, particularly to Edward Rochester. This paper focuses on how the women's resistance against male domination is argued in Charlotte Brontë's Jane Eyre and Jean Rhys's Wide Sargasso Sea through the depiction of Bertha Mason and Antoinette Cosway.

\section{LITERATURE REVIEW}

On a figurative and psychological level, Bertha Mason is suspiciously claimed as the most threatening avatar of Jane Eyre. The series of event which Bertha Mason does is actually the reflection of what Jane Eyre wants to do. When Bertha Mason tears the wedding veil, for example, it reflects what Jane Eyre secretly wants to do as a way of her wish to contest the idea of inequality in marriage (Gilbert and Gubar, 2000, p. 359). Jane Eyre wishes to be Rochester's own equal in size and strength, especially in marriage. This was a particular issue in Victorian society - a wife is, in fact, a belonging to a man, a piece that completes his social life and his private life at home. Jane Eyre wants to battle this mainstream Victorian view in a way that she wants to be Rochester's equal in marriage, not just another mistress he owns.

In addition, the disturbing images of Bertha Mason are also seen as mirroring the fact that she is not only acts for Jane, but she also acts like Jane. The image of Bertha Mason running 'backwards and forwards' on all fours in the attic, for instance, not only showing how figuratively speaking Jane Eyre's own future of being tied in a marriage, but it recalls Jane's life as a governess, whose only relief from mental pain was to pace 'backwards and forwards'. Bertha Mason's animalistic act, and her portrayal of having a 'goblin appearance' seems to mirror Jane Eyre's ten-year-old self, which she was seen as a 'bad animal' imprisoned in the red-room, howling, and mad (Gilbert and Gubar, 2000, p. 359).

As previously mentioned, Wide Sargasso Sea is included in the discussion of a postcolonial literature, where both national and regional consciousness try to assert difference from the imperial center and give the imperial privilege of the center to the marginalized which has been silenced for so long. Jean Rhys reflected the modern postcolonialism, and the use of language she used in Wide Sargasso Sea represents the ability to subvert the ideologies of the West by deconstructing the European discourse and monocentrism. By using language, Rhys emphasized and constructed the racial relationship of the European, the Black, and the 
Creole in her novel. Jean Rhys choice to rewrite the canonical narratives of Western discourse is a common colonial practice where the telling of a story from another point of view is considered an extension of the deconstruction in exploring the gaps and the silenced in a text. This case is obvious in a way that Rhys confronts Brontë's text by giving a voice to Edward Rochester's mad wife, Bertha Mason Rochester.

In writing Wide Sargasso Sea, Rhys herself was deeply influenced by her Creole heritage. The shift in between point of views in Wide Sargasso Sea is effective in how Antoinette and her husband's relationship can be seen from different angles, especially through the eyes of her husband who is white and English - something we do not gain in reading Jane Eyre by Brontë. As a Creole herself, Rhys is personally aware of the conflicting culture, which is reflected by the figure of Antoinette, who is accepted neither within the Black community nor by the Whites. Antoinette belongs to the creolized white community which was a minority group and regarded negatively by both British whites and local Blacks, making her position in relation to the blacks is not well defines and is contradictory. Therefore, the situation of Antoinette is Rhys's writing in relation to her marginal role and her identity becomes essential. Wide Sargasso Sea is a novel about Creole identities and race relation, themes of displacement, and the groups' different relationship with home, specifically the question related to the concept of identity.

Antoinette has the urge to know her personal identity-where she comes from, which group she belongs to - and from Rhys's perspective, when Antoinette is compelled to forget her past and forced to accept the identity given to her, these are a problem of destruction, confusion and oppression related to the self-identity. Bhabha's mimicry is mirrored by Antoinette, particularly in how she mimics the dominant ideas and conceals her own as an attempt to find her own identity. The sense of superior/inferior relation also implies in the novel in how Rochester reveals his self-centeredness even with language. He turns the name 'Antoinette' into 'Bertha', his favorite and ideal name for a British woman. Jean Rhys portrays the characters of Rochester and Antoinette to describe and define wider race relations typical of the West Indies where Europeans born or living there, educated to conceive of England as 'home' were culturally marked and excluded as inferior colonials. Theme like religion also appears in the novel, for example the appearance of voodoo and the tales of Obeah as the greater transcendental power believed by the people in the West Indies. Overall, it is clear that from the novel the postcolonial discourse rises in the form of several themes, from voodoo to customs, to dialects, to race relations and displacement (Capello, 2009, pp. 47-54).

Despite of Antoinette's mother history of mental illness, critics have pointed out that the biggest trigger of Antoinette's madness is actually her husband's oppression towards her. Taking Daniel Cosway's statement about Antoinette, Rochester decided to transport her wife from the West Indies to England where he permanently imprisons his wife. Antoinette is destroyed by her husband who is jealous, sexually insecure, believes that his revenge can be completely justified by vengefully punishing his wife (Gruesser, 2003, pp. 99-109).

From the point of view of feminist theory, there must be efforts done by woman as a reaction to any form of oppression. Through the life of Antoinette Cosway we can see of 
how her position is actually doubly victimized because of her gender and her Creole status. Being non-European and a married woman, particularly being married to an English man, had placed her into an easily oppressed party. In fact, when we are referring to Antoinette Cosway's case, we cannot just simply put this into a simple layer where she is oppressed just because of gender inferiority, we should also take her experience of being a Creole into account.

Judged by the evolving nineteenth-century ideology of femininity, which emphasized women's roles as nurturing mothers and gentle companions and housekeepers for their husbands, women of color were practically placed as anomalies, especially when the ideology of womanhood is related to the idea of slavery. When it comes to female slaves, it was profitable to exploit them. In some cases, the slavery was in fact worse than how it was done to men. Slave women were regarded as genderless; they could be exploited, punished and repressed in whatever ways possible (Davis, 1994, p.10). For instance, since slave women were classified as 'breeders' as opposed to 'mothers,' their infant children could be sold away from them like calves from cows. As females, slave women were inherently vulnerable to all forms of sexual coercion and violent punishments, as well as raped.

When it comes to postcolonial context, racism also has major role to play. The feminist discourse and the ethnic conflict both are the issue that should be tackle, especially regarding to Antoinette Cosway's situation, where in terms of identity, she is neither white nor black. In addition, when it comes to women of Third World countries, the access to equality might particularly be harder than expected, in comparison to the Western countries, especially considering the history of colonialism (Bulbeck, 1998, pp. 18-19). In this case, to situate Antoinette Cosway's resistance to the domination, we should still consider both her experience of being a Creole and her inferior gender position. In this discussion we need to be aware of the fact within the context of slavery, the status of white Creole women remained peculiar, indeed anomalous, and after Emancipation in 1833 they were even more isolated from the women of color they had colonized. In Wide Sargasso Sea Antoinette Cosway's narrative, a dream-like telescoping of time and place, parallels the Creole's historical displacement (Kamel, 1996, pp. 1-22).

\section{RESEARCH METHODOLOGY}

This is a descriptive research. The primary texts used in this paper are Charlotte Brontë's Jane Eyre, and Jean Rhys's Wide Sargasso Sea. The secondary materials include books and journal articles on feminist literary theory and previous related studies on Jane Eyre and Wide Sargasso Sea. The discussion on both texts will be in the form of comparative and will be following the literature review section.

\section{FINDINGS AND DISCUSSION}

Antoinette Cosway and Rochester's marriage, as what have been mentioned before, is an arrangement done by the latter's father and brother. Rochester, in particular, has no interest 
in marrying Antoinette Cosway. In fact, he is only interested in her money. Antoinette, knowing that she has no prior knowledge of her husband to be, and seeing how 'strange' the English gentleman is, refuses to be married. She protests and even tells her half-brother Richard Mason that this was a mistake, and she has no intention of marrying this man.

"You don't know anything about me," she said.

"I'll trust you if you trust me. Is that a bargain? You will make me very unhappy if you send me away without telling me what have I done to displease you. I will go with a sadd heart."

"Your sad heart," she said and touched my face. I kissed her fervently, promising her peace, happiness, safety, but when I said, "Can I tell poor Richard that it was a mistake? He is sad too," she did not answer me. Only nodded. (Rhys, 1992, pp. 71-72)

This attempt, however, fails miserably. Rochester still gets to sweet-talk Antoinette into marrying him, and Richard Mason confronts her by forcing her to marry and give him 'peace' by agreeing to the arranged marriage.

Antoinette soon learns that by marrying Rochester, she has lost both her rightful claim of her properties and her freedom as a woman. She is seen merely as a property that belongs to her husband and can be treated in a way that whichever he likes. In Wide Sargasso Sea, Rhys wrote:

"He will not come after me. And you must understand I am not rich now, I have no money of my own at all, everything I had belongs to him... That is English law.” (Rhys, 1992, p. 100)

Automatically, by the English law, the slaves that belong to Antoinette should be Rochester's as well. This is what justifies his action when he beds one of the slaves named Amelie. Rochester seems to have no worry regarding to his marital status to Antoinette. It can be seen in:

...That is what I remember most about that encounter. She was so gay, so natural and something of this gaiety she must have given to me, for I had not one moment of remorse. Nor was I anxious to know what was happening behind the thin partition which divided us from my wife's bedroom. (Rhys, 1992, p. 126)

Frustrated and mad about the affair, Rochester's action triggers the anger in Antoinette. At the same time, he perceives this anger differently by assuming that his wife has gone mad just like her mother, and she needs an immediate help.

Rochester decided to bring his wife to England with him with the reason of getting proper medication. However, for days he begins calling her 'Bertha' to deny his wife's Creole background. Antoinette, of course, resists to be addressed by such name. 
Prologue: Journal on Language and Literature Vol.7 No.1 (2021)

"Don't laugh like that, Bertha."

"My name is not Bertha; why do you call me Bertha?"

"Because it's a name I'm particularly fond of. I think of you as Bertha." (Rhys, 1992, p. 122)

This doesn't happen once. Rochester repeatedly denies of Antoinette's own identity by calling her a name he claims to "particularly fond of". Antoinette, of course, resists this.

"Yes," she said, "of course, but will you come in and say goodnight to me?"

"Certainly I will, my dear Bertha."

"Not Bertha tonight," she said.

"Of course, on this of all nights, you must be Bertha." (Rhys, 1992, p.123)

She resists the identity given by her husband, claiming that she has her identity on her own, and that she is 'Antoinette'. At times she confronts her husband especially when he tries to control her of telling her of what to and what not to do, she refuses mainly because she is reminded of his affair, which by Rochester is seen as another sign of madness.

The door of Antoinette's room opened. When I saw her I was too shocked to speak. Her hair hung combed and dull into her eyes which were inflamed and staring, her face was very flushed and looked swollen. Her feet were bare. However, when she spoke her voice was low, almost inaudible.

"Don't drink any more," I said.

"And what right you have to tell me what I'm to do?..." (Rhys, 1992, p. 132)

In Jane Eyre, Bertha Mason is seen as a mad woman who savagely plunges her teeth into the arm of her stepbrother and attacks him with a knife. She also repeatedly attempts to kill Rochester (Brontë, 2014, pp. 152, 205). In the final section of Wide Sargasso Sea, in a conversation with Antoinette Cosway, she also points out how Antoinette attacks Richard Mason as if she was a savage. It is written:

Grace Poole said, "So you don't remember that you attacked this gentleman with a knife? I said that you would be quiet, "I must speak to her", he said. Oh he was warned but he wouldn't listen. I was in the room but I didn't hear all he said except "I cannot interfere legally between yourself and your husband". It was when he said "legally" that you flew at him and when he twisted the knife out of your hand, you bit him. Do 
you mean to say that you don't remember any of this?" (Rhys, 1992, p. 165)

However, in Wide Sargasso Sea we can also see how these attacks come from Antoinette's longing to go out from her imprisonment. The physical attacks driven to some people, especially directed to Rochester are none other than her attempt to resist the domination and her voice of wanting to be freed from the attic which jailed her. Antoinette is aware that she has no control of herself and that her marriage has put her into the mercy of her husbandwhich she does not get at all.

In Jane Eyre, when Jane finds out that Thornfield has been destroyed by the fire, and that Bertha Mason the madwoman is the one who caused it, the focus is given to the Rochester and how he is badly injured because of the fire. Bertha Mason, in this case, is described only as 'a lady - a lunatic who is kept in the house'.

"They guessed, ma'am: they guessed. Indeed, I should say it was ascertained beyond a doubt. You are not perhaps aware," he continued, edging his chair a little nearer the table, and speaking low, "that there was a lady - a - a lunatic, kept in the house?"

"She was kept in very close confinement, ma'am; people even for some years was not absolutely certain of her existence. No one saw her: they only knew by rumour that such a person was at the Hall; and who or what she was it was difficult to conjecture. They said Mr Edward had brought her from abroad, and some believed she had been his mistress..." (Brontë, 2014, p. 418)

In the final section of Wide Sargasso Sea, however, we may see a different perspective of this event. Antoinette commits suicide by setting the fire to the house and jumping into her death, freeing herself from the house that has been her prison for so long. 'It was red and all my life was in it' is her final thought of the fire that slowly burns her to death.

...I sat there quietly. I don't know how long I sat. then I turned round and saw the sky. It was red and all my life was in it... Now at last I know why I was brought here and what I have to do. There must have been a draught for the flame flickered and I thought it was out. But I shielded it with my hand and it burned up again to light me along the dark passage. (Rhys, 1992, pp. 170-171)

This is the most apparent and the peak of Antoinette's resistance to the domination that represses her. She chooses to end her life, in Jane Eyre, it may seem like an insane woman who has placed Rochester into such an unfortunate situation. However, as we see it from Wide Sargasso Sea, this event marks Antoinette's final triumph in resisting and winning 
against the domination that has imprisoned her and had been causing her mental illness for years.

\section{CONCLUSION}

Through Jean Rhys's Wide Sargasso Sea, the image of the madwoman in the attic as seen in Charlotte Brontë's Jane Eyre is told from a different perspective. Wide Sargasso Sea acts as a prequel written by Rhys as her reaction to Jane Eyre, and the novel contains a postcolonial discourse as well as feminist discourse. Bertha Mason, who in Wide Sargasso Sea is known as Antoinette Cosway is given a story, a background, and most importantly a voice - in a way that she has become more than just a mad woman who is locked inside Thornfield's attic in Brontë's classic text. Despite some of the similarities in plot, the text by Rhys is different in which it shows the form of resistance, based on how Antoinette resist to follow the domination, which is a breakthrough for Brontë's work that shows Bertha Mason as a minor figure, moreover, lunatic. The act of resistance in Jane Eyre may seem like it is a normal thing to be done by a mentally disturbed person, however, if we compare it to Wide Sargasso Sea we may conclude that the act of resistance (e.g. refuse to marry refuse to be called Bertha, physical attack, etc.) is actually Antoinette's way of confronting against the race and gender based domination she experiences.

\section{References}

Brennan, Z. (2010) Brontë's Jane Eyre. London: Continuum Books.

Brontë, C. (2014) Jane Eyre. London: Arcturus Publishing.

Bulbeck, C.(1998) Re-orienting Western Feminisms. United Kingdom: Cambridge University Press.

Capello, S. (2009) Postcolonial Discourse in "Wide Sargasso Sea": Creole Discourse vs. European Discourse, Periphery vs. Center, and Marginalized People vs. White Supremacy. Journal of Caribbean Study 6.1.

Davis, A. (1994) Women, Race and Class. New York: Random House Inc.

Gilbert, S. and Gubar, S. (2000) The Madwoman in the Attic: The Woman Writer and the Nineteenth-Century Literary Imagination $2^{\text {nd }} e d$. United States: Yale University Press.

Gruesser, J. (2003) Say Die and I Will Die: Betraying the Other, Controlling Female Desire and Legally Destroying Women in Wide Sargasso Sea and Othello. Journal of Caribbean Literatures 3.3.

Kamel, R. (1996) Before I was Set Free: The Creole Wife in Jane Eyre and Wide Sargasso Sea. The Journal of Narrative Technique 25.1.

Rhys, J. (1992) Wide Sargasso Sea. New York: W. W. Norton \& Company Ltd. 